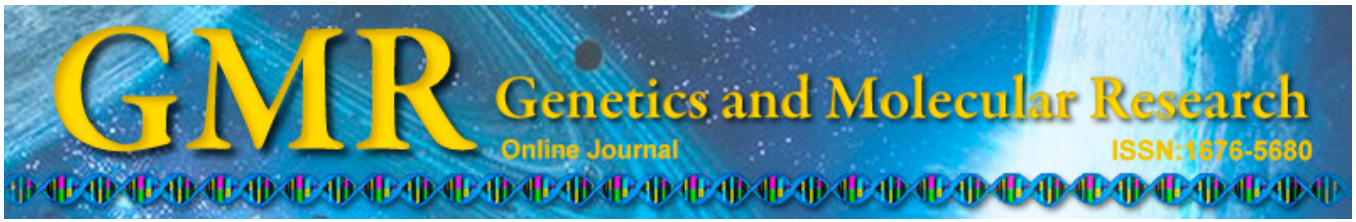

\title{
Physical mapping of the Period gene on meiotic chromosomes of South American grasshoppers (Acridomorpha, Orthoptera)
}

\author{
T.E. Souza ${ }^{1,2}$, D.L. Oliveira ${ }^{1}$, J.F. Santos ${ }^{1}$ and T.T. Rieger ${ }^{1,2}$ \\ ${ }^{1}$ Laboratório de Experimentação em Drosophila, Departamento de Genética, \\ Centro de Ciências Biológicas, Universidade Federal de Pernambuco, \\ Recife, PE, Brasil \\ ${ }^{2}$ Programa de Pós-Graduação em Genética, Departamento de Genética, \\ Centro de Ciências Biológicas, Universidade Federal de Pernambuco, \\ Recife, PE, Brasil
}

Corresponding author: T.T. Rieger

E-mail: tania.rieger@pq.cnpq.br

Genet. Mol. Res. 13 (4): 10829-10836 (2014)

Received January 7, 2014

Accepted April 20, 2014

Published December 19, 2014

DOI http://dx.doi.org/10.4238/2014.December.19.4

\begin{abstract}
The single-copy gene Period was located in five grasshopper species belonging to the Acridomorpha group through permanent in situ hybridization (PISH). The mapping revealed one copy of this gene in the L1 chromosome pair in Ommexecha virens, Xyleus discoideus angulatus, Tropidacris collaris, Schistocerca pallens, and Stiphra robusta. A possible second copy was mapped on the L2 chromosome pair in S. robusta, which should be confirmed by further studies. Except for the latter case, the chromosomal position of the Period gene was highly conserved among the four families studied. The $S$. robusta karyotype also differs from the others both in chromosome number and morphology. The position conservation of the single-copy gene Period contrasts with the location diversification
\end{abstract}


of multigene families in these species. The localization of single-copy genes by PISH can provide new insights about the genomic content and chromosomal evolution of grasshoppers and others insects.

Key words: Period gene; Grasshoppers; Meiotic chromosomes; Permanent in situ hybridization (PISH); Evolution

\section{INTRODUCTION}

Sensu stricto grasshoppers are within the monophyletic superfamily grouping Acridomorpha of the Orthoptera order (Song, 2010). This group contains about 24 superfamilies, including the Acridoidea superfamily, which is the largest within Orthoptera and contains about 11 families and 7680 species defined by the phallic complex morphology, among other characteristics (Eades, 2000; Song, 2010). Among these families are Ommexechidae, Romaleidae, and Tristiridae, which are endemic to Neotropical regions and have a probable origin in South America. Although Acrididae has a worldwide distribution, 10 subfamilies are represented in the Neotropics, and five of them are exclusive to this geographical region (Carbonell, 1977). Recent molecular studies (Matt et al., 2008) support the removal of the Proscopiidae family from the Proscopioidea superfamily and its inclusion in the Eumastacoidea superfamily, to which it has a closer affinity, as proposed by Eades (2000).

The grasshopper species Ommexecha virens Thunberg, 1824 (Ommexechidae), Xyleus discoideus angulatus Stål, 1873 (Romaleidae), Tropidacris collaris Stoll, 1813 (Romaleidae), Schistocerca pallens Thunberg, 1815 (Acrididae), and Stiphra robusta Mello-Leitão, 1939 (Proscopiidae) are found in almost all of northeastern Brazil. The last three species are considered to be scattered pests, causing damage to various cultivars and associated native vegetation (Magalhães and Lecoq, 2007). They have symmetrical karyotypes showing slightly decreasing chromosome sizes with a predominant acrocentric morphology, conserved number ( 23 for males and 24 for females), and XO sex-chromosome system (Mesa et al., 1982). Exceptions are the submetacentric morphology of the largest chromosomal pair (L1) in O. virens (Mesa and Ferreira, 1977) and a lower diploid number ( $2 \mathrm{n}=19$ for males and 20 for females) in S. robusta (de Souza and Moura, 2000).

The physical positions of the clock gene Period were mapped in meiotic chromosomes of five South American grasshopper species using the permanent in situ hybridization technique (PISH) (Rieger et al., 2007). The data obtained for this single-copy gene were compared to those in the literature for other single-copy genes and repetitive-copy genes in order to obtain evolutionary insights.

\section{MATERIAL AND METHODS}

\section{Specimens and cytological preparations}

The species, number of specimens, and geographical coordinates of sampling points are presented in Table 1. All samples were registered and preserved as part of the insect collection of Departamento de Genética (Centro de Ciências Biológicas, UFPE, Recife, PE, Brazil), and all institutional and national guidelines for the care and use of laboratory animals were followed. After the capture, specimens were dissected, and the testes were fixed in Carnoy 
solution (3:1 ethanol and acetic acid) and stored in a freezer. Slides were prepared by the classical technique of squashing a testicular follicle in $45 \%$ acetic acid. After freezing in liquid nitrogen to remove the coverslip, all preparations were stored at $4^{\circ} \mathrm{C}$ until hybridization. The best preparations were used for PISH according to Rieger et al. (2007). For the in situ hybridization procedures, five slides of representatives of each species were used.

$\begin{aligned} & \text { Table 1. Number of grasshopper male specimens and geographical coordinates of collection places in the states } \\
& \text { of Pernambuco (PE), Piauí (PI), Paraíba (PB), and Bahia (BA) in northeastern Brazil. }\end{aligned}$
\begin{tabular}{lcll}
\hline Species & Number of specimens & Collection places & Coordinates \\
\hline Ommexecha virens & 2 & Sobradinho, BA & $09^{\circ} 26^{\prime} 15^{\prime \prime} \mathrm{S}, 40^{\circ} 48^{\prime} 45^{\prime \prime} \mathrm{W}$ \\
& 3 & Mucugê, BA & $13^{\circ} 03^{\prime} 45^{\prime \prime} \mathrm{S}, 41^{\circ} 18^{\prime} 45^{\prime \prime} \mathrm{W}$ \\
Xyleus discoideus angulatus & 2 & Marcolândia, PI & $07^{\circ} 26^{\prime} 15^{\prime \prime} \mathrm{S}, 40^{\circ} 41^{\prime} 15^{\prime \prime} \mathrm{W}$ \\
& 1 & Exu, PE & $07^{\circ} 30^{\prime} 50^{\prime \prime} \mathrm{S}, 39^{\circ} 42^{\prime} 33^{\prime \prime} \mathrm{W}$ \\
Tropidacris collaris & 3 & Recife, PE & $08^{\circ} 01^{\prime} 05^{\prime \prime} \mathrm{S}, 34^{\circ} 56^{\prime} 48^{\prime \prime} \mathrm{W}$ \\
& 1 & Andaraí, BA & $12^{\circ} 48^{\prime} 45^{\prime \prime} \mathrm{S}, 41^{\circ} 18^{\prime} 45^{\prime \prime} \mathrm{W}$ \\
Schistocerca pallens & 4 & Itamaracá, PE & $07^{\circ} 41^{\prime} 15^{\prime \prime} \mathrm{S}, 34^{\circ} 48^{\prime} 45^{\prime \prime} \mathrm{W}$ \\
Stiphra robusta & 7 & Fagundes, PB & $07^{\circ} 21^{\prime} 18^{\prime \prime} \mathrm{S}, 35^{\circ} 46^{\prime} 30^{\prime \prime} \mathrm{W}$ \\
\hline
\end{tabular}

\section{Plasmid amplification and probe preparations}

The probes were prepared from the pTOPZiper01 plasmid containing the flanking sequences of the threonine-glycine region of the Period gene of the drosophilid Zaprionus indianus cloned in the TOPO TA plasmid (Invitrogen, USA) (Müller et al., 2012). Plasmids were transformed into the DH5 $\alpha$ strain of Escherichia coli with the calcium chloride method and extracted by alkaline lysis (Ausubel et al., 2002). Whole plasmids were biotin labeled by nick translation using the BioNick DNA system as indicated by the manufacturer (Gibco/BRL, Paisley, Scotland) to be used as probes.

\section{PISH procedures}

The in situ hybridization procedures were performed as described for the first time for grasshoppers by Rieger et al. (2007). Briefly, hybridizations were carried out at $37^{\circ} \mathrm{C}$ in $30 \%$ formamide for $36 \mathrm{~h}$ by using $200 \mathrm{ng}$ biotin-labeled probe for each slide. Washes were performed at room temperature with $2 \mathrm{X}$ saline-sodium citrate buffer, adopting a stringency level of $65 \%$ (Schwarzacher and Heslop-Harrison, 2000). The streptavidin-alkaline phosphatase conjugate, nitro blue tetrazolium, and bromo-chloro-indolyl-phosphate were used to detect the hybridization sites as the visualization of dark blue spots over the chromosomes. After hybridization, the chromosome preparations were counterstained with lactic orcein ( $1 \%$ orcein in $20 \%$ lactic acid and $45 \%$ acetic acid) diluted 1:10 in $45 \%$ acetic acid, air dried, and mounted in Entellan (Merck). The PISH signals in the chromosomes were analyzed and documented under phasecontrast microscopy. Because heterologous probes were used, the signals were quantified as described previously by Campos et al. (2007) and Rieger et al. (2007), establishing a minimum of $30 \%$ signals at a chromosome site as the criterion of consistent gene localization.

\section{RESULTS}

An arrangement of chromosomes in groups according to size is proposed here for the 
S. robusta karyotype as shown in Figure 1. Their chromosomes are assigned to two groups as follows: four pairs of large chromosomes (L1-L4), five pairs of medium chromosomes (M5M9), and a large X chromosome.

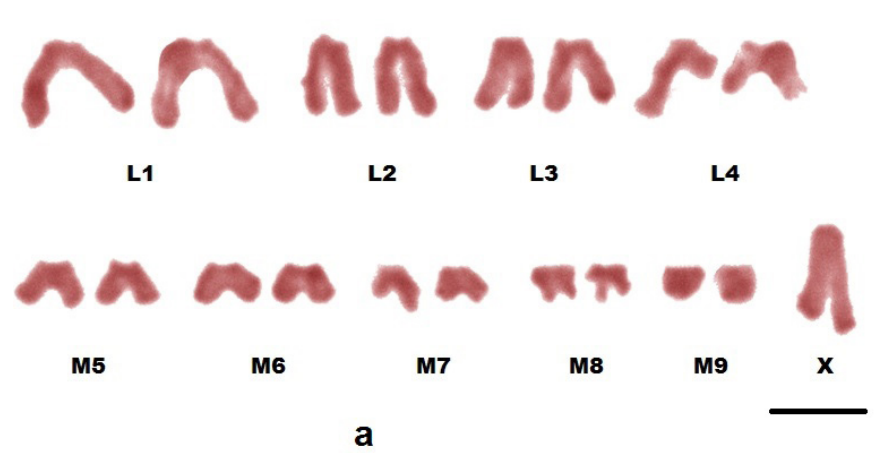

a

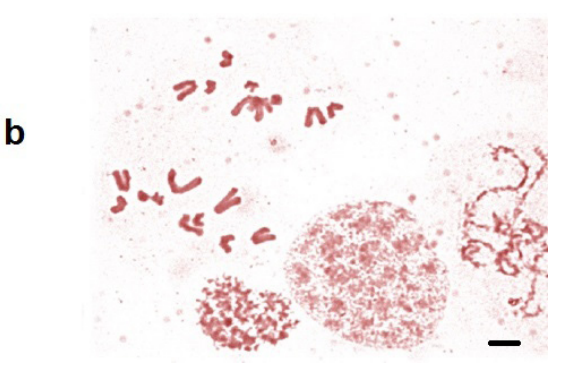

Figure 1. New arrangement of the Stiphra robusta karyotype according to chromosome sizes using the nomenclature used for other species of grasshoppers (a). Chromosomes were obtained from an anaphase I cell (b). Bar $=10 \mu \mathrm{m}$.

Using the PISH technique, the single-copy gene Period was located in meiotic chromosomes of $O$. virens, $X$. discoideus angulatus, T. collaris, S. pallens, and S. robusta. For all five species, at least 100 nuclei were analyzed (Table 2). The efficiency of the in situ hybridization ranged from 54 to $80 \%$. Hybridization marks in these chromosomes are shown in Figure 2.

\begin{tabular}{|c|c|c|c|c|c|c|c|c|c|c|c|c|c|c|c|c|c|}
\hline \multirow[t]{2}{*}{ Species } & \multirow{2}{*}{$\begin{array}{c}\text { Number of } \\
\text { nuclei analyzed }\end{array}$} & \multirow{2}{*}{$\begin{array}{c}\text { Percent of } \\
\text { nuclei marked }\end{array}$} & \multicolumn{15}{|c|}{ Percent of marked chromosomes } \\
\hline & & & $\overline{\mathrm{L} 1}$ & L2 & L3 & L4 & M3 & M4 & M5 & M6 & M7 & M8 & M9 & S9 & $\mathrm{S} 10$ & $\mathrm{~S} 11$ & $\mathrm{X}$ \\
\hline Ommexecha virens & 169 & 62 & 48 & 12 & 13 & * & $*$ & 28 & - & - & - & - & $*$ & 5 & - & - & 5 \\
\hline Tropidacris collaris & 164 & 63 & 51 & 13 & $*$ & * & 14 & 9 & 11 & - & - & - & $*$ & 9 & - & - & 9 \\
\hline Xyleus discoideus angulatus & 250 & 54 & 45 & 19 & 13 & $*$ & $*$ & 9 & 10 & - & - & - & * & 5 & 5 & - & 10 \\
\hline Schistocerca pallens & 100 & 56 & 39 & 12 & 12 & $*$ & $*$ & 3 & - & - & - & 23 & $*$ & 5 & - & - & 5 \\
\hline Stiphra robusta & 221 & 80 & 70 & 46 & 21 & 15 & $*$ & $*$ & 15 & 15 & 11 & 11 & 11 & $*$ & $*$ & $*$ & 4 \\
\hline
\end{tabular}

The asterisk indicates that the chromosome number does not apply to that species. 


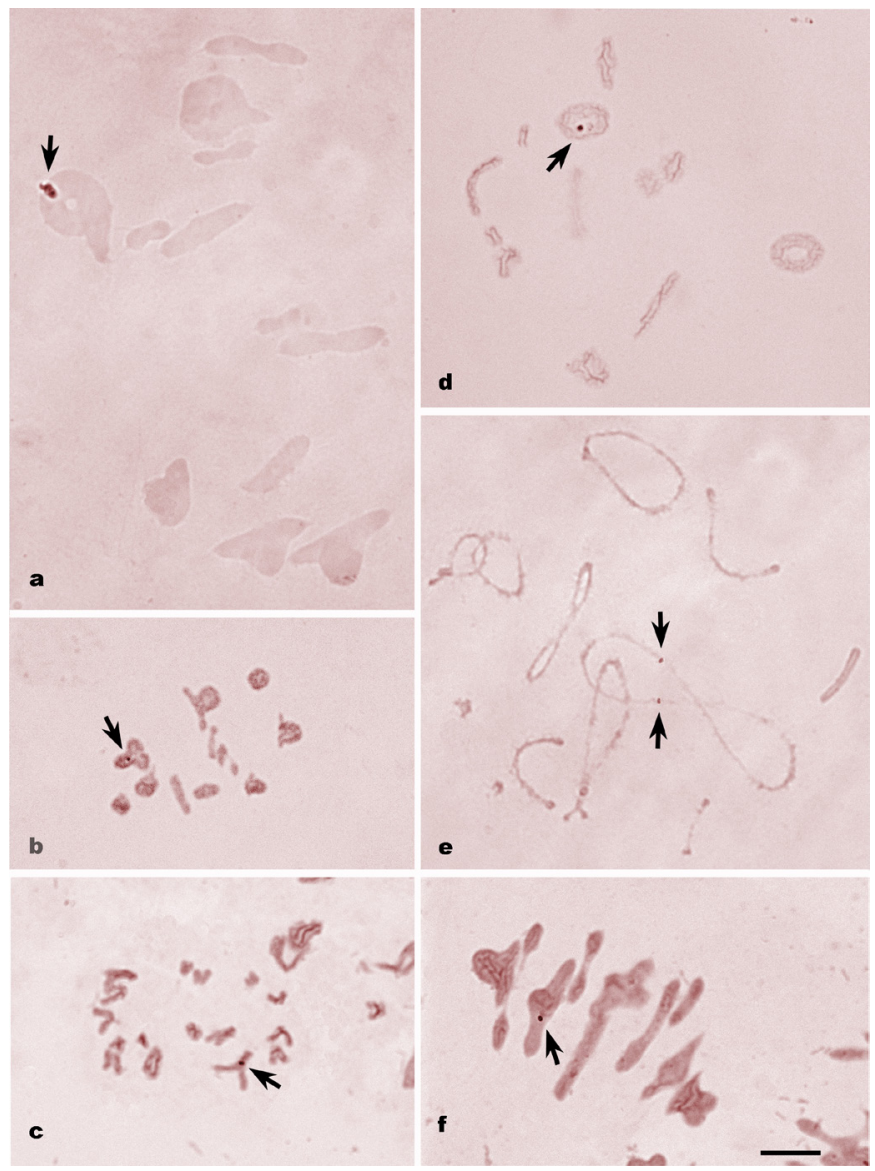

Figure 2. Chromosomal location of the Period gene on the L1 chromosome pair (arrows) by permanent in situ hybridization (PISH) in a Tropidacris collaris metaphase I cell (a), Ommexecha virens metaphase I cell (b), Xyleus discoideus angulatus metaphase I cell (d), Schistocerca pallens diplotene cell (e), Stiphra robusta anaphase I cell (c), and on the L2 chromosomal pair of a Stiphra robusta metaphase I cell (f). The photographs were taken at the same magnification. Bar $=10 \mu \mathrm{m}$.

\section{DISCUSSION}

The karyotypes of $O$. virens (Carvalho et al., 2011), X. discoideus angulatus (Souza et al., 1998), and S. pallens (Souza and Melo, 2007) were characterized by basic cytogenetic techniques, such as $\mathrm{C}$ banding and silver nitrate impregnation. In these species, $2 \mathrm{n} \hat{0}=23$ chromosomes was found, and chromosomes were generally arranged as three pairs of large chromosomes (L1-L3), five pairs of medium chromosomes (M4-M8), three pairs of small chromosomes (S9-S11), and the X chromosome, which is considered to be a medium-sized chromosome. While T. collaris has the same chromosome number as most orthopterans, it differs in chromosome morphology, presenting two pairs of large chromosomes (L1-L2), six pairs of medium chromosomes (M3-M8), three pairs of small chromosomes (S9-S11), and a medium-sized X chromosome (Mesa et al., 1982). A similar chromosome grouping clas- 
sification was adopted in this study for S. robusta to facilitate chromosome and karyotype comparisons because there is not such a description in the literature. It is noteworthy that the S. robusta karyotype differs from other species in this study, both in chromosome number and in chromosome sizes, with four chromosome pairs in the large group, five pairs in the medium group, and a large X chromosome. This species did not have small chromosomes like those seen in other Proscopiidae members, such as Scleratoscopia protopeirae (Cabral-de-Mello et al., 2011a). The M3 chromosome pair of T. collaris corresponds to the L3 pair in the other species in this study, but it is placed in the medium chromosome group because of its smaller size. The homology of chromosomal content among species is yet to be examined. The same observations must be made regarding the L4 chromosome pair of S. robusta, which, although placed in the large chromosome group due to its bigger size, may correspond to the M4 pair in the other species.

Single-copy gene mapping is routinely carried out in several dipteran species such as Drosophila (Ranz et al., 2001; Evgen'ev et al., 2004) and Zaprionus species (Campos et al., 2007) because of the facility of polytene chromosomes. Locating single-copy genes can be useful when comparing karyotypes of species, like the comparison of the Drosophila genus performed by Clark et al. (2007), or even to compare karyotypes in close genera or different species and families of dipterans. In situ hybridization of single-copy genes can be also applied to mitotic or meiotic chromosomes and used to compare the location of single-copy genes in orthopteran karyotypes (Rieger et al., 2007). There are not studies about the Period gene location in grasshoppers. Most of the research done with this gene was the molecular characterization of the threonine-glycine repeating regions in some groups, mainly Diptera and Lepidoptera, allowing the use of this gene as a marker in phylogeographic studies, molecular systematics, and evolution. These studies demonstrated the considerable level of evolutionary conservation and feasibility of using this gene, alone or combined with other markers, for applications in systematic, taxonomic, and population studies of insect groups (Rosato and Kyriacou, 2001; Miyatake et al., 2002; Barr et al., 2005; Mazzotta et al., 2005; Lankinen and Forsman, 2006; Sawyer et al., 2006; Matsumoto et al., 2008).

The most remarkable finding in this study was the conservation of the chromosomal location of the Period gene in the five species that were analyzed. This gene was located on the L1 chromosomal pair in all five analyzed species, displaying conservation in the interstitial chromosome position. The position of the Period gene was conserved in four families, which included three families (Romaleidae, Ommexechidae, and Acrididae) from the Acridoidea superfamily and the Proscopiidae family. This probably reflects the conservation of gene content in orthopterans. Only S. robusta seemed to carry a second copy of the Period gene near the centromere of the L2 chromosome, which, if confirmed in other Proscopiidae species, possibly represents a typical condition of this ancient grasshopper family (Flook et al., 2000). Thus, karyotype differentiation and gene content agree with the proposal of Eades (2000) to move the Proscopiidae family from the Proscopioidea superfamily to the Eumastacoidea superfamily.

A previous report by Rieger et al. (2007) described the mapping of single-copy genes in $S$. pallens. In this Acrididae representative, the $H s p 70$ gene was detected as a single locus on the L2 chromosome, although there are some species groups in Drosophila (Diptera) in which this locus is duplicated (Segarra et al., 1996). The Hsp83, Hsp27, and Ubi genes were also mapped to $S$. pallens chromosomes by Rieger et al. (2007). The Hsp83 gene was present as a single locus in all investigated insect species, and its position in $S$. pallens defined the first landmark that was available to identify the M7 chromosome pair. Duplication of the Hsp27 
and $U b i$ loci was indicated in this species, and the main copy of $H s p 27$ and Ubi mapped to the L1 and L2 chromosomes, respectively.

The physical localization of repetitive-copy genes was determined for several grasshopper species. The $45 \mathrm{~S}$ rDNA was observed in dispersed sites in the karyotypes of $O$. virens (Carvalho et al., 2011), X. discoideus angulatus (Souza et al., 1998), S. pallens (Souza and Melo, 2007), and others. The 5S and 18S families and the histone H3 gene presented several marks on medium chromosome pairs of S. robusta and other Proscopiidae species (Cabral-deMello et al., 2011a). The chromosomal location of 5S rDNA in a large number of Acrididae species revealed its position mainly on medium and small chromosomes. The $5 \mathrm{~S}$ rDNA localization showed a variable number of signals, from a single chromosome pair in some species to all pairs in others (Cabral-de-Mello et al., 2011b). From the localization studies multigene families present dispersive location patterns, even in near species. This is in clear contrast to single-copy genes, such as Period (this study) and heat shock genes (Rieger et al., 2007), which maintain positions on the same chromosome in very distant grasshopper families.

An increased number of mapped genes in multiple grasshopper species will allow us to make important evolutionary inferences. Although it may seem premature, the positioning of the Period gene on the same chromosome pair in the five grasshopper species described in this study may indicate that, besides the similar karyotypes, grasshopper species may also share gene synteny, as demonstrated for drosophilids and other dipterans (Campos et al., 2007; Schaeffer et al., 2008).

\section{ACKNOWLEDGMENTS}

The authors thank Heverson Aslan and Nicole Leoni for English revisions and the Brazilian agencies Conselho Nacional de Desenvolvimento Científico e Tecnológico (CNPq) and Fundação de Amparo à Ciência do Estado de Pernambuco (FACEPE) for fellowships to D.L. de Oliveira and T.E. de Souza (\#IBPG-0643-2.02/09).

\section{REFERENCES}

Ausubel F, Brent R, Kingston RE, Moore DD, et al. (2002). Short Protocols in Molecular Biology. John Wiley and Sons. Inc., Hoboken.

Barr NB, Cui L and McPheron BA (2005). Molecular systematics of nuclear gene period in genus Anastrepha (Tephritidae). Ann. Entomol. Soc. Am. 98: 173-180.

Cabral-de-Mello DC, Cabrero J, Lopez-Leon MD and Camacho JP (2011a). Evolutionary dynamics of 5S rDNA location in acridid grasshoppers and its relationship with $\mathrm{H} 3$ histone gene and 45S rDNA location. Genetica 139: 921-931.

Cabral-de-Mello DC, Martins C, Souza MJ and Moura RC (2011b). Cytogenetic mapping of 5S and 18S rRNAs and H3 histone genes in 4 ancient Proscopiidae grasshopper species: contribution to understanding the evolutionary dynamics of multigene families. Cytogenet. Genome Res. 132: 89-93.

Campos SR, Rieger TT and Santos JF (2007). Homology of polytene elements between Drosophila and Zaprionus determined by in situ hybridization in Zaprionus indianus. Genet. Mol. Res. 6: 262-276.

Carbonell CS (1977). Origin, evolution and distribution of the neotropical acridomorph fauna (Orthoptera): a preliminary hypothesis. Rev. Soc. Entomol. Argent. 36: 153-175.

Carvalho DB, Rocha MF, Loreto V, Silva AE, et al. (2011). Ommexecha virens (Thunberg, 1824) and Descampsacris serrulatum (Serville, 1831) (Orthoptera, Ommexechidae): karyotypes, constitutive heterochromatin and nucleolar organizing regions. Comp. Cytogenet. 5: 123-132.

Clark AG, Eisen MB, Smith DR, Bergman CM, et al. (2007). Evolution of genes and genomes on the Drosophila phylogeny. Nature 450: 203-218.

de Souza MJ and de Moura RC (2000). Karyotypic characterization and constitutive heterochromatin in the grasshopper Stiphra robusta (Orthoptera: Proscopiidae). Cytobios 101: 137-144. 
Eades DC (2000). Evolutionary relationships of phallic structures of Acridomorpha (Orthoptera). J. Orthoptera Res. 9: 181-210.

Evgen'ev MB, Zatsepina OG, Garbuz D, Lerman DN, et al. (2004). Evolution and arrangement of the hsp70 gene cluster in two closely related species of the virilis group of Drosophila. Chromosoma 113: 223-232.

Flook PK, Klee S and Rowell CH (2000). Molecular phylogenetic analysis of the Pneumoroidea (Orthoptera, Caelifera): molecular data resolve morphological character conflicts in the basal acridomorpha. Mol. Phylogenet. Evol. 15: 345-354.

Lankinen P and Forsman P (2006). Independence of genetic geographical variation between photoperiodic diapause, circadian eclosion rhythm, and Thr-Gly repeat region of the period gene in Drosophila littoralis. J. Biol. Rhythms 21: 3-12.

Magalhães BP and Lecoq M (2007). Bioinseticida e Gafanhotos-Praga. Relatório Final do Projeto: Desenvolvimento de Bioinseticidas para Controle de Gafanhotos-Praga no Brasil. Embrapa Recursos Genéticos e Biotecnologia, Brasília.

Matsumoto A, Ohta Y, Itoh TQ, Sanada-Morimura S (2008). Period gene of Bactrocera cucurbitae (Diptera: Tephritidae) among strains with different mating times and sterile insect technique. Ann. Entomol. Soc. Am. 101: 1121-1130.

Matt S, Flook PK and Rowel CHF (2008). A partial molecular phylogeny of the Eumastacoidea s. lat. (Orthoptera, Caelifera). J. Orthoptera Res. 17: 43-55.

Mazzotta GM, Sandrelli F, Zordan MA, Mason M, et al. (2005). The clock gene period in the medfly Ceratitis capitata. Genet. Res. 86: 13-30.

Mesa A and Ferreira A (1977). Cytological studies in the family Ommexechidae (Orthoptera: Acridoidea). Acrida 6: 261-271.

Mesa A, Ferreira A and Carbonell CS (1982). Cariologia de los acridoideos neotropicales: estado actual de su conocimiento y nuevas contribuciones. Annis Soc. Ent. Fr. 18: 526.

Miyatake T, Matsumoto A, Matsuyama T, Ueda HR, et al. (2002). The period gene and allochronic reproductive isolation in Bactrocera cucurbitae. Proc. Biol. Sci. 269: 2467-2472.

Müller MJ, Mendonca MP, Oliveira IR, de Oliveira LP, et al. (2012). Courtship behavior of Zaprionus indianus (Gupta) (Diptera: Drosophilidae) from populations colonizing South America. Neotrop. Entomol. 41: 112-120.

Ranz JM, Casals F and Ruiz A (2001). How malleable is the eukaryotic genome? Extreme rate of chromosomal rearrangement in the genus Drosophila. Genome Res. 11: 230-239.

Rieger TT, Oliveira-Silva SV, Pacheco IA, Chagas BS, et al. (2007). Localization of HSP single-copy genes by inexpensive, permanent non-fluorescent in situ hybridization on meiotic chromosomes of the grasshopper Schistocerca pallens (Acrididae). Genet. Mol. Res. 6: 643-649.

Rosato E and Kyriacou CP (2001). Flies, clocks and evolution. Philos. Trans. R. Soc. Lond. B. Biol. Sci. 356: 1769-1778.

Sawyer LA, Sandrelli F, Pasetto C, Peixoto AA, et al. (2006). The period gene Thr-Gly polymorphism in Australian and African Drosophila melanogaster populations: implications for selection. Genetics 174: 465-480.

Schaeffer SW, Bhutkar A, McAllister BF, Matsuda M, et al. (2008). Polytene chromosomal maps of 11 Drosophila species: the order of genomic scaffolds inferred from genetic and physical maps. Genetics 179: 1601-1655.

Schwarzacher T and Heslop-Harrison P (2000). Practical In Situ Hybridization. BIOS Scientific Publishers Limited, Oxford.

Segarra C, Ribo G and Aguade M (1996). Differentiation of Muller's chromosomal elements D and E in the obscura group of Drosophila. Genetics 144: 139-146.

Song H (2010). Grasshopper systematics: past, present and future. J. Orthoptera Res. 19: 57-68.

Souza MJ and Melo NF (2007). Chromosome study in Schistocerca (Orthoptera-Acrididae-Cyrtacanthacridinae): karyotypes and distribution patterns of constitutive heterochromatin and nucleolus organizer region (NORs). Genet. Mol. Biol. 30: 54-59.

Souza MJ, Rufas JS and Orellana J (1998). Constitutive heterochromatin, NOR location and FISH in the grasshopper Xyleus angulatus (Romaleidae). Caryologia 51: 73-80. 